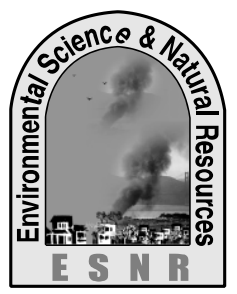

\title{
Effect of Sodium Chloride on Growth and Development of Sodium Accumulating Halophytes in Saline Water
}

\author{
M. M. L. Hosen ${ }^{1}$, M. S. Islam ${ }^{1 *}$, M. N. Uddin ${ }^{1}$, K. A. Haque ${ }^{1}$ and M. S. Islam ${ }^{2}$ \\ ${ }^{1}$ Department of Agricultural Chemistry, ${ }^{2}$ Department of Post Harvest Technology and Marketing, \\ Patuakhali Science and Technology University, Dumki, Patuakhali-8602 \\ *Corresponding author: sharifulpstu@yahoo.com
}

\begin{abstract}
Effect of $\mathrm{NaCl}$ on nutrient uptake was observed from a phytodesalination study by three abundantly grown sodium accumulating halophytes namely, Kalmilata (Ipomoea aquatica), Malancha (Alternanthera philoxeroides) and Kesordam (Ludwigia adscendens L.). A 45 days hydroponic experiment was conducted with these halophytes treated with $0,3,5$ and $7 \mathrm{dS} \mathrm{m}^{-1}$ salt added from the sodium chloride $(\mathrm{NaCl})$. After analyzing water and plant parts, it was observed that potassium $(\mathrm{K})$ and phosphorus $(\mathrm{P})$ uptake were increased by plants and less effect on calcium $(\mathrm{Ca})$, magnesium $(\mathrm{Mg})$ and chloride $\left(\mathrm{Cl}^{-}\right)$uptake due to added $\mathrm{NaCl}$. Simultaneously the biomass content increased in Kalmilata rather than Malancha and Kesordam. So non-altered nutritional status makes these halophytes suitable for vegetable, fodder and forages use after phytodesalination of saline water.
\end{abstract}

Key words: Accumulating, Halophytes, Saline, Sodium, Water

\section{Introduction}

Salinity is a major risk to crop production in coastal areas of Bangladesh. The prevailing salinity intrusion due to climate change has severely affecting the crop productivity in the saline regions of Bangladesh (Haque et al., 2014). About $20 \%$ of the net cultivable land of Bangladesh coastal region is affected by various degree of salinity (Karim and Mimura, 2008). But this percentages increasing day by day due to different kinds of natural disasters like cyclones, tidal storms, floods etc. in our country, the salinity problem decrease the yield of rice production every year. There are some plants that that hyperaccumulate toxic metals from water environment called phytoremediation (Islam et al., 2015). Phytodesalination is one of the phytoremediation techniques where some halophytes can reduce salinity from saline water. Halophytes can uptake potassium $(\mathrm{K})$ phosphorus $(\mathrm{P})$, calcium $(\mathrm{Ca})$, magnesium $(\mathrm{Mg})$ and chloride $\left(\mathrm{Cl}^{-}\right)$ion in addition to sodium ion from the saline water or added sodium chloride $(\mathrm{NaCl})$ condition. Here in this study artificially $\mathrm{NaCl}$ was added to the water to study the effect of $\mathrm{NaCl}$ on $\mathrm{K}, \mathrm{P}, \mathrm{Ca}, \mathrm{Mg}$ and $\mathrm{Cl}^{-}$uptake by the halophytes. The used halophytes such as Kalmilata (Ipomoea aquatica), Malancha (Alternanthera philoxeroides) and Kesordam (Ludwigia adscendens) absorb $\mathrm{K}, \mathrm{P}, \mathrm{Ca}, \mathrm{Mg}$ and $\mathrm{Cl}^{-}$ion in the added $\mathrm{NaCl}$ condition. Abdelly et al. (1995) demonstrated that some halophytes (such as Suaeda salsa, Suaeda fruticosa, Arthtrocnemum indicum, Halocnemum strobulaceum etc.) can remove enormous sodium quantities from soil and accumulate them in their shoots. Ravindran et al. (2007) evaluated also in six halophytes to reduce salinity in the upper $40 \mathrm{~cm}$ of soil. Halophytes are of significant interest since these plants are naturally present in environments with an excess of $\mathrm{Na}^{+}$ions and research findings suggested that these plants have the high potentiality to desalinize the saline water. In this phytodesalination experiment, the effect of $\mathrm{NaCl}$ on plant biomass content and the uptake of $\mathrm{K}, \mathrm{P}, \mathrm{Ca}, \mathrm{Mg}$ and $\mathrm{Cl}^{-}$were studied.

\section{Materials and Methods}

A pot experiment was conducted in natural condition of the Department of Agricultural Chemistry, Patuakhali Science and Technology University. The total numbers of pots $(30 \mathrm{~cm} \times 30 \mathrm{~cm} \times 21 \mathrm{~cm})$ were 36 . Kalmilata (Ipomoea aquatica), Malancha (Alternanthera philoxeroides) and Kesordam (Ludwigia adscendens) were used in this experiment for the purpose of phytodesalination of saline water. The plant seedlings were collected from nonsaline areas of Dumki, Patuakhali district. Four salinity levels viz. $0,3,5$ and $7 \mathrm{dS} \mathrm{m}^{-1}$ were artificially made from sodium chloride $(\mathrm{NaCl})$ and added separately in different pots. Then each of three halophytes was cultured for 45 days in each pot. Hoagland nutrient solution was added as a nutrient source for hydroponic plant culture (Hoagland and Arnon, 1950). The experiment was laid out in a Completely Randomized Design (CRD) with three replications. Water samples were collected from each pot at initial of experiment and after harvesting of plants. The plants were harvested carefully at 45 days of transplanting and separated into root, stem and leaf. After drying, the root, stem and leaf weights were recorded separately. 0.2 to $0.5 \mathrm{~g}$ plant sample was digested by wet oxidation method using di-acid mixture $\left(\mathrm{HNO}_{3}: \mathrm{HClO}_{4}=2: 1\right)$. The concentration of $\mathrm{Ca}$ and $\mathrm{Mg}$ were determined by complexometric method of titration using $\mathrm{Na}_{2}$-EDTA as a complexing agent (Page et al., 1982 and APHA, 2005). P was determined by ascorbic acid color development method with the help of spectrophotometer (T60UV) while $\mathrm{Na}$ and $\mathrm{K}$ in the samples were determined separately with the help of flame emission spectrophotometer (Jenway PEP-7) using appropriate filters as outlined by Page et al. (1982) and APHA (2005). Chloride was determined from water samples by argentometric method of titration (Skoog et al., 1996). Results were expressed as the means \pm standard error of mean (SEM) of three replicates. Significance degree was calculated using a $t$ test. 


\section{Results and Discussion}

\section{Effects of added $\mathrm{NaCl}$ on biomass content of halophytes}

Less dramatic fluctuations among the treatment are shown in case of biomass content of halophytes. For artificial salt treated water, biomass content of Malancha leaf significantly $(\mathrm{p}<0.01)$ decreased with increasing level of treatments (Table 1). On the other hand, growth of Kesordam leaf and root was significantly $(\mathrm{p}<0.05)$ increased at 3 and $7 \mathrm{dS} \mathrm{m} \mathrm{m}^{-1}$ salt treatment, respectively, though there was no significant change in biomass content of stem compare to control. At the same time, in case of Kalmilata higher biomass was found in root, stem and leaf due to vigorous growth in both saline and non-saline water. According to Hasanuzzaman et al. (2014) those halophytes having high biomass content can grow under salinity stress condition and suitable phytodesalinator. So these growth factors of Kalmilata exclusively indicted their potentiality as phytodesalinator to reduce salinity in water.

Na uptake in halophytes at elevated water salinity level $\mathrm{Na}$ uptake was significantly increased with increasing levels of soil $\mathrm{NaCl}$. The $\mathrm{Na}$ uptake increased progressively in root, stem and leaf with increased levels of $\mathrm{NaCl}$. $\mathrm{Na}$ accumulation was recorded in root, stem and leaf separately (Table 2). In all selected species, the highest accumulation was found in the root of Malancha $\left(145.63 \mathrm{~g} \mathrm{~kg}^{-1}\right)$ at $7 \mathrm{dS} \mathrm{m}^{-1}$ treatment while the lowest was in the root of Kesordam $\left(25.53 \mathrm{~g} \mathrm{~kg}^{-1}\right)$ at $0 \mathrm{dS} \mathrm{m}^{-1}$ treatment (Table 2). It was noted that root and leaf accumulated the higher amount of $\mathrm{Na}$ as compared to stem for Malancha, Kalmilata and Kesordam. Rabhi et al. (2010) found that leaves, stems, and roots of Sesuvium portulacastrum plants grown on salinized soil contained 149.9, 87.7 and $37.4 \mathrm{mg} \mathrm{Na}^{+} \mathrm{g}^{-1}$ DW, respectively, which are strongly support the current results.

\section{Effect of $\mathrm{NaCl}$ on $\mathrm{K}$ uptake by halophytes}

In most cases of artificially $\mathrm{NaCl}$ added soil, the uptake of $\mathrm{K}$ increased with increasing $\mathrm{NaCl}$ level in root stem and leaf of halophytes. The highest accumulation of $\mathrm{K}$ was found in the stem of Kalmilata $\left(30.64 \mathrm{~g} \mathrm{~kg}^{-1}\right)$ at 7 $\mathrm{dS} \mathrm{m}^{-1}$ treatment (Fig. 1a) while the lowest in the root of Kesordam $\left(2.87 \mathrm{~g} \mathrm{~kg}^{-1}\right)$ at $0 \mathrm{dS} \mathrm{m}^{-1}$ treatment (Fig. 1c). Compare to others leaves, $\mathrm{K}$ accumulation was higher in the leaf of Malancha $\left(29.64 \mathrm{~g} \mathrm{~kg}^{-1}\right)$ at $7 \mathrm{dS} \mathrm{m}^{-1}$ treatment and the lowest in the leaf of Malancha $(4.58 \mathrm{~g}$ $\mathrm{kg}^{-1}$ ) at $0 \mathrm{dS} \mathrm{m}^{-1}$ treatment (Fig. 1b). Jlassi et al. (2013) also found that $\mathrm{K}$ concentration in Sulla carnosa was $6.33 \mathrm{~g} \mathrm{~kg}^{-1}$ under salinated conditions. But in this study the $\mathrm{K}$ concentration is high which might be due to the different physiological factors for different plants. Sesuvium portulacastrum plants also grown on salinized soil contained $15.7,30.5$ and $17.6 \mathrm{mg} \mathrm{K}^{+} \mathrm{g}^{-1} \mathrm{DW}$, respectively which give consistency in the current research findings (Rabhi et al., 2010)

Effect of $\mathrm{NaCl}$ on Ca uptake by halophytes
A significant relationship was found between the added $\mathrm{NaCl}$ and $\mathrm{Ca}^{2+}$ uptake in $\mathrm{NaCl}$ accumulating halophytes. Calcium uptake significantly increased $(p<0.01)$ with increasing rates of added salts for stem and leaf of Kalmilata at higher salt concentration (Fig. 2a). The highest accumulation was found in the root of Malancha (7.3\%) at $7 \mathrm{dS} \mathrm{m}^{-1}$ treatment (Fig. 2b) while the lowest in the stem of Kalmilata and Malancha $(1.4 \%)$ at $3 \mathrm{dS} \mathrm{m}^{-1}$ and $0 \mathrm{dS} \mathrm{m}^{-1}$ treatment. But a negative relationship between $\mathrm{NaCl}$ and $\mathrm{Ca}^{2+}$ was found for uptake of $\mathrm{Ca}$ by all root, stem and leaf of Kesordam at $7 \mathrm{dS} \mathrm{m}^{-1}$ compare to their respective control (Fig. 2c). $\mathrm{Ca}$ accumulation was found in roots of all halophytes compare to their respective stem and leaf (Fig. 2). This result is also consistent with the Jlassi et al. (2013) who showed that $\mathrm{Ca}$ concentration in Sulla carnosa was about 4.5\%. Rabhi et al. (2010) also found that Sesuvium portulacastrum plants also grown on salinized soil contained $2.31,4.51$ and $2.18 \% \mathrm{Ca}^{2+}$, respectively.

\section{Effect of NaCl on P uptake by halophytes}

$\mathrm{P}$ uptake enhanced with increasing levels of added $\mathrm{NaCl}$ for root of all halophytes. With the increasing of added $\mathrm{NaCl}$ the uptake of $\mathrm{P}$ by the roots of the halophytes was increasing significantly (Fig. 3). The highest accumulation was found in the root of Malancha (37.97 $\mathrm{mg} \mathrm{L}^{-1}$ ) at $7 \mathrm{dS} \mathrm{m}^{-1}$ treatment (Fig. 3b) while the lowest in the stem of Kesordam $\left(3.73 \mathrm{mg} \mathrm{L}^{-1}\right)$ at $0 \mathrm{dS} \mathrm{m}^{-1}$ treatment (Fig. 3c). The uppermost level of $\mathrm{P}$ accumulation was found in the root of Malancha (37.97 $\mathrm{mg} \mathrm{L}^{-1}$ ) at $7 \mathrm{dS} \mathrm{m}^{-1}$ treatment while the lowermost in the root of Kalmilata $\left(5.15 \mathrm{mg} \mathrm{L}^{-1}\right)$ at $0 \mathrm{dS} \mathrm{m}^{-1}$ treatment (Fig. 3).

\section{Effect of $\mathrm{NaCl}$ on $\mathrm{Mg}$ uptake by halophytes}

There were no significant differences of $\mathrm{Mg}$ uptake among root, stem and leaf of Kalmilata but significant difference $(p<0.05)$ was found in the leaf of Malancha and Kesordam at 5 and $7 \mathrm{dS} \mathrm{m}^{-1}$ salinity treatment (Fig. 4). $\mathrm{Mg}$ uptake in root was always higher than stem and leaf. The highest $\mathrm{Mg}$ accumulation was found in the root of Malancha $\left(4.53 \%\right.$ ) at $5 \mathrm{dS} \mathrm{m}^{-1}$ treatment (Fig. 4b) while the lowest in the leaf of Kesordam (0.37\%) at $0 \mathrm{dS} \mathrm{m} \mathrm{m}^{-1}$ treatment (Fig. 4c). In root, the $\mathrm{Mg}$ concentrations ranged from 2.52-3.76, 2.59-4.53 and 0.8-1.76 for Kesordam, Malancha and Kalmilata, respectively. In stem, the $\mathrm{Mg}$ concentration ranged from $1.13-1.43,0.58-0.98$ and $0.77-1.14 \%$ for Kesordam, Malancha and Kalmilata, respectively. Among different stems, $\mathrm{Mg}$ accumulation was found higher in the Kesordam stem $(1.43 \%)$ at $7 \mathrm{dS} \mathrm{m}^{-1}$ treatment (Fig. 4c) while the lowest in the stem of Malancha $(0.58 \%)$ at 0 $\mathrm{dS} \mathrm{m}^{-1}$ treatment (Fig. 4b). The maximum $\mathrm{Mg}$ accumulation was found in the leaf of Kesordam $(1.56 \%)$ at $7 \mathrm{dS} \mathrm{m}^{-1}$ treatment while the minimum in the leaf of Kesordam $(0.37 \%)$ at $0 \mathrm{dS} \mathrm{m}^{-1}$ treatment (Fig. $4 \mathrm{c})$ compare with other plants leaves at other treatments. Rabhi et al. (2010) examined that Sesuvium portulacastrum plants grown on salinized soil contained $0.456,0.501$ and $0.484 \% \mathrm{Mg}^{2+}$, respectively, which is strongly co-related with current findings. Sulla carnosa 
halophytes also contained about $0.54 \% \mathrm{Mg}$ under saline conditions (Jlassi et al. 2013).

\section{$\mathrm{K}, \mathrm{Ca}, \mathrm{Mg}, \mathrm{P}$ and $\mathrm{Cl}^{-}$at initial and final phytodesalinated water}

$\mathrm{K}, \mathrm{Ca}, \mathrm{Mg}, \mathrm{P}$ and $\mathrm{Cl}^{-}$at initial and final phytodesalinated water after 45 days culturing of Kalmilata, Malancha and Kesordam in 0, 3, 5 and $7 \mathrm{dS}$ $\mathrm{m}^{-1}$ treated water were measured and data were presented in Table 3. All of these elements were decreased in final water indicated that halophytes were capable to uptake these elements from the salinity treated water under salinity stress. $\mathrm{K}, \mathrm{Ca}$ and $\mathrm{Cl}^{-}$were significantly decreased in final water compare to initial water treatment where Kalmilata were grown (Table 3). $\mathrm{K}, \mathrm{P}$ and $\mathrm{Cl}^{-}$were also decreased in Malancha grown final water. But there were not so significant trends in case of other elements (Table 3 ).

Table 1. Oven dry weights (gm) of root, stem, and leaf after 45 days culturing of Kalmilata, Malancha and Kesordam in $0,3,5$ and $7 \mathrm{dS} \mathrm{m}^{-1}$ treated water

\begin{tabular}{|c|c|c|c|c|}
\hline \multirow{3}{*}{ Plant name } & \multirow{2}{*}{ Treatment } & \multicolumn{3}{|c|}{ Plant part (dry weight) } \\
\cline { 2 - 5 } & 0 & Root & Stem & Leaf \\
\hline \multirow{3}{*}{ Kalmilata } & 3 & $0.36 \pm 0.03$ & $1.25 \pm 0.04$ & $1.63 \pm 0.13$ \\
\cline { 2 - 5 } & 5 & $0.36 \pm 0.08$ & $2.27 \pm 0.46$ & $1.10 \pm 0.17$ \\
\cline { 2 - 5 } & 7 & $0.37 \pm 0.03$ & $1.72 \pm 0.14$ & $1.14 \pm 0.19$ \\
\hline \multirow{3}{*}{ Malancha } & 0 & $0.38 \pm 0.07$ & $1.82 \pm 0.19$ & $1.33 \pm 0.03$ \\
\cline { 2 - 5 } & 3 & $0.27 \pm 0.01$ & $2.06 \pm 0.03$ & $* * 0.67 \pm 0.02$ \\
\cline { 2 - 5 } & 5 & $0.32 \pm 0.04$ & $1.92 \pm 0.07$ & $* * 0.65 \pm 0.04$ \\
\hline \multirow{3}{*}{ Kesordam } & 7 & $0.28 \pm 0.03$ & $* * 1.54 \pm 0.04$ & $0.45 \pm 0.03$ \\
\cline { 2 - 5 } & 0 & $0.29 \pm 0.01$ & $1.44 \pm 0.18$ & $* 0.58 \pm 0.01$ \\
\cline { 2 - 5 } & 3 & $0.30 \pm 0.04$ & $1.47 \pm 0.27$ & $0.44 \pm 0.05$ \\
\cline { 2 - 5 } & 5 & $0.35 \pm 0.08$ & $1.37 \pm 0.03$ & $0.50 \pm 0.03$ \\
\hline
\end{tabular}

Each value indicated as Mean $\pm \mathrm{SE}(\mathrm{n}=3) ; * *$ and $*$ showed significantly difference against control or $0\left(\mathrm{dS} \mathrm{m}^{-1}\right)$ at $\mathrm{p}<0.01$ and 0.05 , respectively.

Table 2. Na contents in root, stem, leaf of Kalmilata, Malancha and Kesordam after 45 days culturing at 0, 3, 5 and $7 \mathrm{dS}$ $\mathrm{m}^{-1}$ salt treated water

\begin{tabular}{|c|c|c|c|c|c|c|c|c|c|}
\hline \multirow{2}{*}{ Treatment } & \multicolumn{3}{|c|}{ Kalmilata } & \multicolumn{3}{|c|}{ Malancha } & \multicolumn{3}{|c|}{ Kesordam } \\
\hline & Root & Stem & Leaf & Root & Stem & Leaf & Root & Stem & Leaf \\
\hline 0 & $\begin{array}{c}86.12 \pm \\
0.4\end{array}$ & $\begin{array}{c}64.18 \pm 0 \\
4\end{array}$ & $39.59 \pm 0.4$ & $87.16 \pm 0.1$ & $65.5 \pm 0.3$ & $45.21 \pm 0.4$ & $\begin{array}{c}25.53 \pm 0 \\
.2\end{array}$ & $\begin{array}{c}65.67 \pm 0 \\
4\end{array}$ & $\begin{array}{c}64.65 \pm 0 \\
1\end{array}$ \\
\hline 3 & $\begin{array}{c}* * 95.2 \\
8 \pm 0.4\end{array}$ & $\begin{array}{c}* 67.36 \pm 0 \\
.6\end{array}$ & $\begin{array}{c}* * 76.87 \pm \\
0.7\end{array}$ & $\begin{array}{c}* * 111.34 \\
\pm 1\end{array}$ & $\begin{array}{c}* * 70.97 \pm \\
0.3\end{array}$ & $\begin{array}{c}* * 102.34 \\
\pm 0.4\end{array}$ & $\begin{array}{c}* * 85.26 \\
\pm 1\end{array}$ & $\begin{array}{c}* * 77.39 \pm \\
0.5\end{array}$ & $\begin{array}{c}* * 95.61 \pm \\
0.5\end{array}$ \\
\hline 5 & $\begin{array}{l}* * 102 . \\
79 \pm 0.3\end{array}$ & $\begin{array}{c}* * 77.62 \pm \\
0.4\end{array}$ & $\begin{array}{c}* * 98.69 \pm \\
2\end{array}$ & $\begin{array}{c}* * 129.73 \\
\pm 1\end{array}$ & $\begin{array}{c}* * 70.63 \pm \\
0.3\end{array}$ & $\begin{array}{c}* * 103.57 \\
\pm 0.3\end{array}$ & $\begin{array}{c}* * 91.3 \pm \\
0.3\end{array}$ & $\begin{array}{c}* * 79.88 \pm \\
1.4\end{array}$ & $\begin{array}{c}* * 94.68 \pm \\
0.3\end{array}$ \\
\hline 7 & $\begin{array}{c}* * 100 . \\
4 \pm 1.1\end{array}$ & $\begin{array}{c}* * 79.58 \pm \\
0.6\end{array}$ & $\begin{array}{c}* * 101.52 \\
\pm 0.3\end{array}$ & $\begin{array}{c}* * 145.63 \\
\pm 0.2\end{array}$ & $\begin{array}{c}* * 79.27 \pm \\
0.6\end{array}$ & $\begin{array}{c}* * 131.28 \\
\pm 0.3\end{array}$ & $\begin{array}{c}* * 90.7 \pm \\
0.9\end{array}$ & $\begin{array}{c}* * 87.73 \pm \\
0.2\end{array}$ & $\begin{array}{c}* * 92.32 \pm \\
0.8\end{array}$ \\
\hline
\end{tabular}

Each value indicated as Mean $\pm \mathrm{SE}(\mathrm{n}=3) ; * *$ and $*$ showed significantly difference against control or $0\left(\mathrm{dS} \mathrm{m}^{-1}\right)$ at $\mathrm{p}<0.01$ and 0.05 , respectively. 
Table 3. K, Ca, $\mathrm{Mg}, \mathrm{P}$ and $\mathrm{Cl}^{-}$at initial and final phytodesalinated water after 45 days culturing of Kalmilata, Malancha and Kesordam in $0,3,5$ and $7 \mathrm{dS} \mathrm{m}^{-1}$ treated water

\begin{tabular}{|c|c|c|c|c|c|c|c|}
\hline Halophyte & Water & Treatment & $\mathrm{K}\left(\mathrm{mg} \mathrm{L}^{-1}\right)$ & $\mathrm{Ca}(\% \mathrm{mg})$ & $\mathrm{Mg}(\% \mathrm{mg})$ & $\mathrm{P}\left(\mathrm{mg} \mathrm{L}^{-1}\right)$ & $\mathrm{Cl}^{-}\left(\mathrm{meL}^{-1}\right)$ \\
\hline \multirow{8}{*}{ Kalmilata } & \multirow{4}{*}{$\begin{array}{l}\text { Initial } \\
\text { water }\end{array}$} & 0 & $156.83 \pm 0.9$ & $8.54 \pm 0.4$ & $11.81 \pm 0.3$ & $61.79 \pm 0.1$ & $19.33 \pm 0.33$ \\
\hline & & 3 & $* * 242.68 \pm 0.1$ & $* * 10.88 \pm 0.2$ & $12.52 \pm 0.3$ & $* * 71.39 \pm 0.6$ & $* * 31 \pm 0.6$ \\
\hline & & 5 & $* * 286.97 \pm 0.2$ & $* * 14.67 \pm 0.4$ & $12.74 \pm 0.2$ & $* * 81.05 \pm 0.4$ & $* 52 \pm 3.5$ \\
\hline & & 7 & $* * 315.45 \pm 0.3$ & $* * 14.27 \pm 0.4$ & $12.18 \pm 0.3$ & $* * 86.43 \pm 0.3$ & $* * 67 \pm 0.6$ \\
\hline & \multirow{4}{*}{$\begin{array}{l}\text { Final } \\
\text { water }\end{array}$} & 0 & $144.86 \pm 1.5$ & $6.69 \pm 0.3$ & $9.5 \pm 0.3$ & $19.17 \pm 9.6$ & $9 \pm 0.6$ \\
\hline & & 3 & $* 153.15 \pm 1.3$ & $* * 10.11 \pm 0.2$ & $* 10.56 \pm 0.2$ & $34.14 \pm 0.3$ & $* * 22.33 \pm 1.2$ \\
\hline & & 5 & $* 155.22 \pm 0.3$ & $* * 11.74 \pm 0.3$ & $* * 11.66 \pm 0.1$ & $* 67.97 \pm 0.6$ & $* * 40.6 \pm 0.7$ \\
\hline & & 7 & $* * 161.75 \pm 1.8$ & $* * 10.55 \pm 0.4$ & $* * 11.45 \pm 0.3$ & $* 75.6 \pm 0.7$ & $* * 51.67 \pm 2.3$ \\
\hline \multirow{8}{*}{ Malancha } & \multirow{4}{*}{$\begin{array}{l}\text { Initial } \\
\text { water }\end{array}$} & 0 & $146.76 \pm 1.3$ & $8.62 \pm 0.3$ & $11.44 \pm 0.3$ & $55.34 \pm 0.2$ & $10.33 \pm 0.3$ \\
\hline & & 3 & $* * 234.83 \pm 0.2$ & $* * 12.24 \pm 0.2$ & $12.27 \pm 0.2$ & $* * 67.89 \pm 0.4$ & $* * 27 \pm 1.7$ \\
\hline & & 5 & $* * 290.93 \pm 0.1$ & $* * 18.36 \pm 0.2$ & $12.6 \pm 0.2$ & $* * 70.37 \pm 1$ & $* 47 \pm 0.6$ \\
\hline & & 7 & $* * 334.21 \pm 1.3$ & $* * 9.75 \pm 0.3$ & $10.3 \pm 0.2$ & $* * 31.03 \pm 1.3$ & $* * 55.67 \pm 0.3$ \\
\hline & \multirow{4}{*}{$\begin{array}{l}\text { Final } \\
\text { water }\end{array}$} & 0 & $145.27 \pm 1.7$ & $9.48 \pm 0.4$ & $9.48 \pm 0.4$ & $18.57 \pm 0.1$ & $6.33 \pm 0.3$ \\
\hline & & 3 & $* * 182.32 \pm 0.2$ & $8.87 \pm 0.2$ & $12.41 \pm 3.3$ & $* * 32.58 \pm 0.1$ & $* 21.33 \pm 1.8$ \\
\hline & & 5 & $* 151.52 \pm 0.6$ & $8.88 \pm 0.2$ & $9.67 \pm 0.2$ & $* * 31.45 \pm 0.4$ & $* * 34.67 \pm 1.8$ \\
\hline & & 7 & $* 155.51 \pm 0.3$ & $10.4 \pm 0.5$ & $10.03 \pm 0.3$ & $* * 34.43 \pm 0.2$ & $* * 49.67 \pm 2.2$ \\
\hline \multirow{8}{*}{ Kesordam } & \multirow{4}{*}{$\begin{array}{l}\text { Initial } \\
\text { water }\end{array}$} & 0 & $115.39 \pm 33$ & $11.36 \pm 0.1$ & $7.5 \pm 0.4$ & $70.33 \pm 0.6$ & $11.67 \pm 0.3$ \\
\hline & & 3 & $* 240.52 \pm 6$ & $* * 14.46 \pm 0.2$ & $* * 12.68 \pm 0.2$ & $* * 82.21 \pm 0.5$ & $* * 32.33 \pm 1.2$ \\
\hline & & 5 & $* 286.49 \pm 0.4$ & $* * 16.62 \pm 0.3$ & $* * 12.57 \pm 0.2$ & $* * 81.98 \pm 0.2$ & $* * 48 \pm 1.2$ \\
\hline & & 7 & $* 321.76 \pm 0.9$ & $13.73 \pm 0.9$ & $* * 12.29 \pm 0.1$ & $* * 77.34 \pm 1$ & $* * 63.33 \pm 1.8$ \\
\hline & \multirow{4}{*}{$\begin{array}{l}\text { Final } \\
\text { water }\end{array}$} & 0 & $160.29 \pm 0.2$ & $11.63 \pm 0.3$ & $11.69 \pm 0.4$ & $29.41 \pm 0.2$ & $8 \pm 0.6$ \\
\hline & & 3 & $160.78 \pm 0.8$ & $10.41 \pm 0.4$ & $* 9.71 \pm 0.5$ & $* * 38.84 \pm 0.8$ & $* 21.67 \pm 1.9$ \\
\hline & & 5 & $161.39 \pm 2.2$ & $* * 8.61 \pm 0.3$ & $* 9.48 \pm 0.4$ & $* * 39.66 \pm 0.2$ & $* * 42 \pm 1.2$ \\
\hline & & 7 & $* 161 \pm 0.1$ & $* 13.55 \pm 0.3$ & $* 9.48 \pm 0.4$ & $* 40.63 \pm 1.3$ & $* * 51 \pm 2.9$ \\
\hline
\end{tabular}

Each value indicated as Mean $\pm \mathrm{SE}(\mathrm{n}=3) ; * *$ and $*$ showed significantly difference against control or $0\left(\mathrm{dS} \mathrm{m}^{-1}\right)$ at $\mathrm{p}<0.01$ and 0.05 , respectively. 

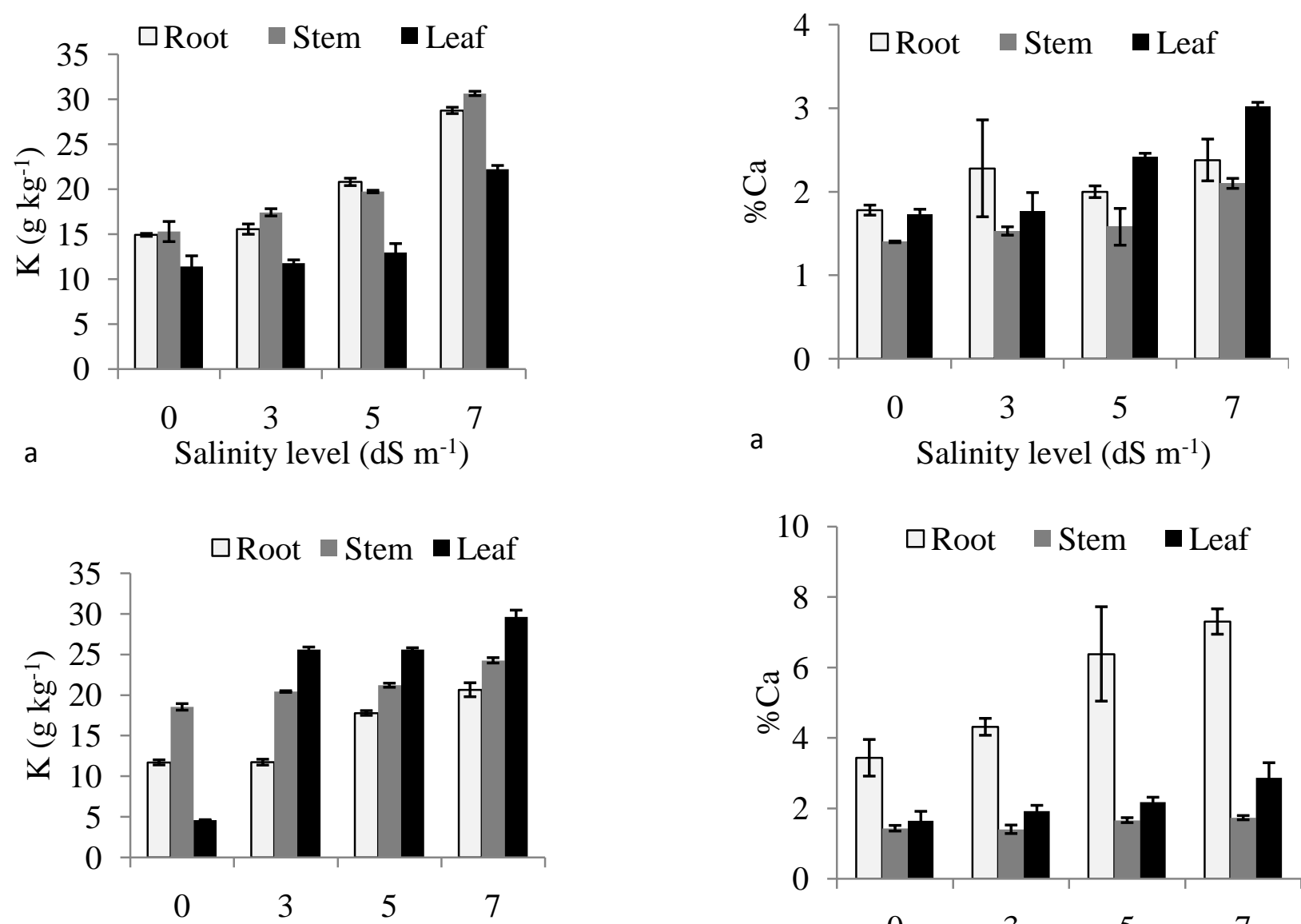

b Salinity level $\left(\mathrm{dS} \mathrm{m}^{-1}\right)$
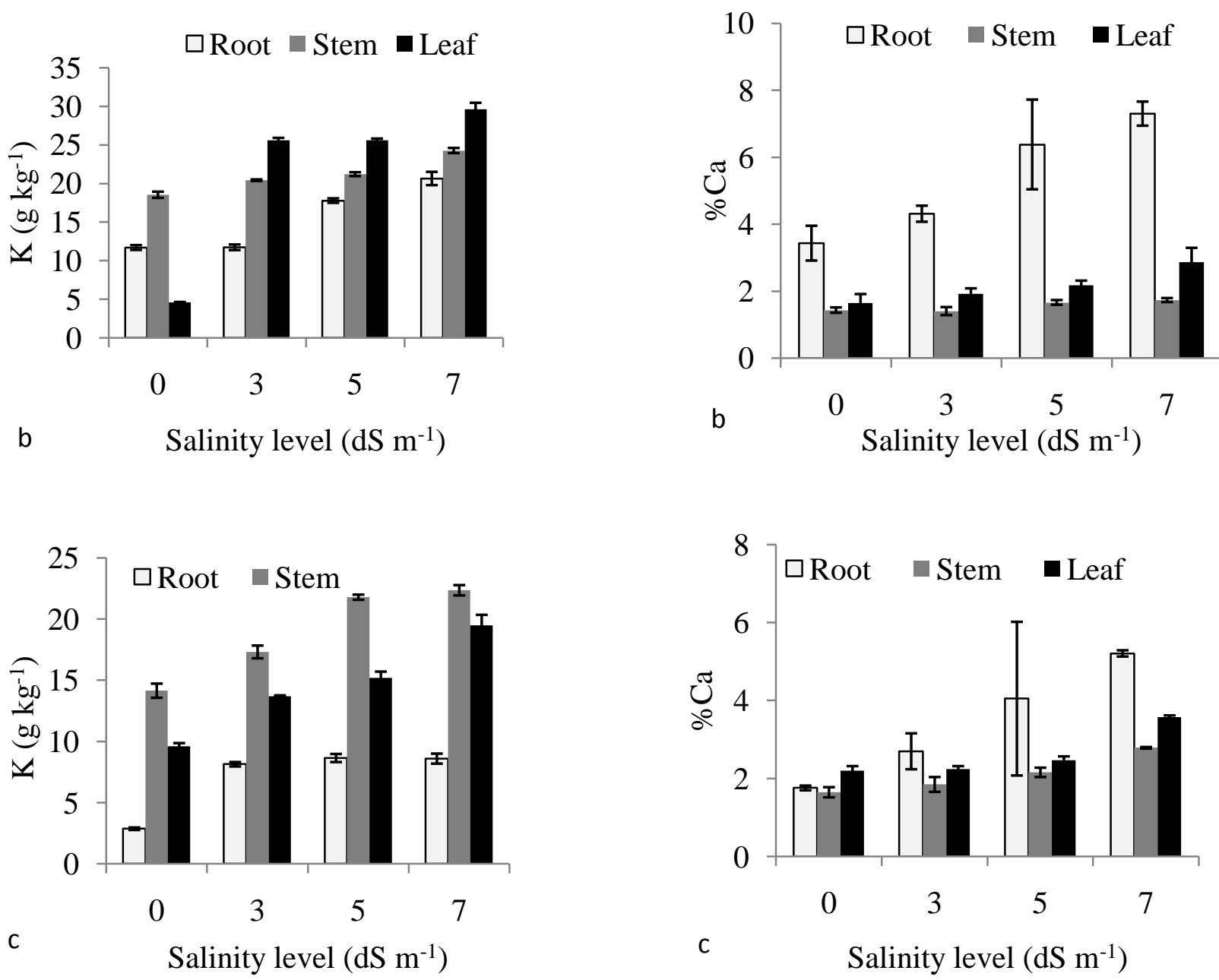

Fig. 1. $\mathrm{K}$ accumulation $\left(\mathrm{g} \mathrm{kg}^{-1}\right)$ in root, stem and leaf of a) Kalmilata, b) Malancha and c) Kesordam at different salinity levels

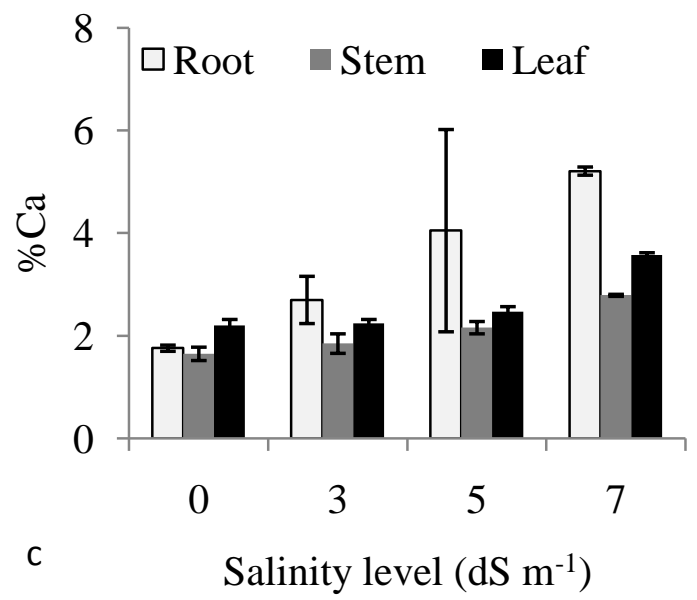

Fig. 2. Ca accumulation (\% Ca) in root, stem and leaf of a) Kalmilata, b) Malancha and c) Kesordam at different salinity levels 

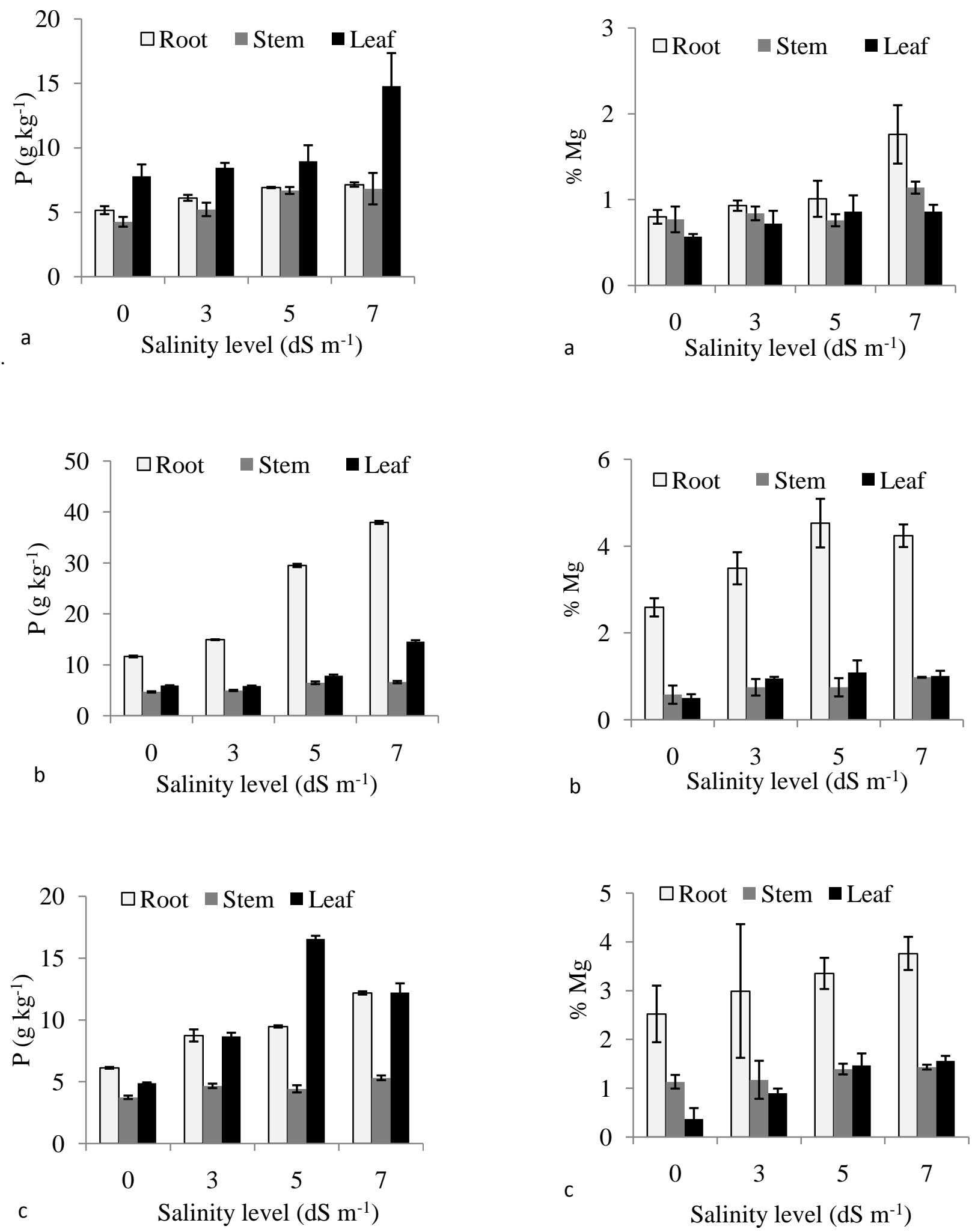

Fig. 3. $\mathrm{P}$ accumulation $\left(\mathrm{g} \mathrm{kg}^{-1}\right)$ in root, stem and leaf of a) Kalmilata, b) Malancha and c) Kesordam at different salinity levels

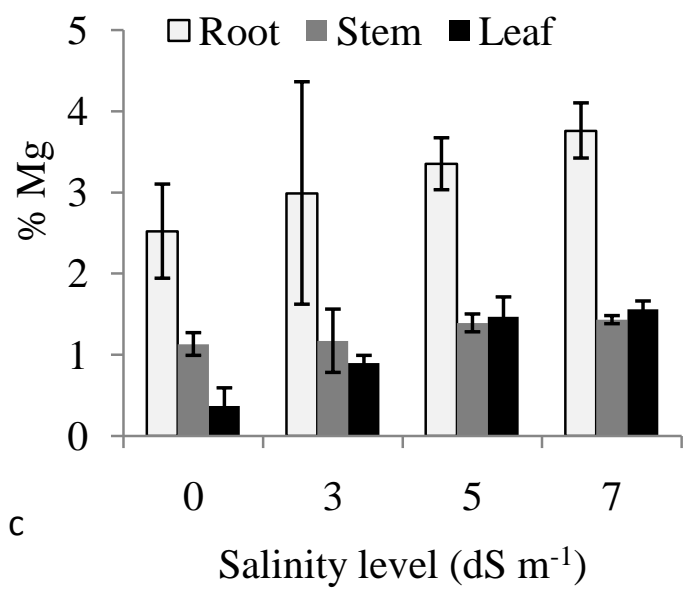

Fig. 4. $\mathrm{Mg}$ accumulation (\% $\mathrm{Mg}$ ) in root, stem and leaf of a) Kalmilata, b) Malancha and c) Kesordam at different salinity level 


\section{Conclusions}

Halophytes are of significant interest since these plants are naturally present in environment and act as very good phytodesalinator which is environmentally safe, economically sound and very efficient. It is concluded that three $\mathrm{Na}$ hyperaccumulating halophytes exhibited positive relationship of added $\mathrm{NaCl}$ with $\mathrm{K}, \mathrm{P}$ ion uptake. Added $\mathrm{NaCl}$ has less effect on $\mathrm{Ca}^{+}, \mathrm{Mg}^{+}$and $\mathrm{Cl}^{-}$ ion uptake by the halophytes. On the other hand, biomass content increased in Kalmilata than Malancha and Kesordam due to added $\mathrm{NaCl}$. The non-altered nutritional status makes these halophytes suitable for using fodder, forage and fuel purposes which will save the environment from secondary contamination from these halophytes after harvesting.

\section{References}

Abdelly, C.; Lachaâl, M.; Grignon, C.; Soltani, A. and Hajji, M. 1995. Association épisodique d'halophytes strictes et de glycophytes dans un écosystème hydromorphe salé en zone semi-aride. Agronomie, 15:557-568.

American Public Health Association (APHA), 2005. American Water Works Association (AWWA) and Water Environment Federation (WEF): Standard Methods for the Examination of Water and Wastewater, 21st Edition.

Haque, M. A.; Jahiruddin, M.; Hoque, M. A.; Rahman, M. Z. and Clarke, D. 2014. Temporal variability of soil and water salinity and its effect on crop at Kalapara upazila. J. Environ. Sci. and Natural Res., 7(2):111-114

Hasanuzzaman, M.; Nahar, K ; Alam, M.; Bhowmik, P. C.; Hossain, M. A.; Rahman, M. M.; Prasad, M. N. V.; Ozturk, M. and Fujita, M. 2014. Potential Use of Halophytes to Remediate Saline Soils. BioMed. Research International,1-12. http://dx.doi.org/10.1155/2014/589341

Hoagland, D. R. and Arnon, D. I. 1950. The Waterculture method for growing plants without soil. Circular. California Agric. Exp. Sta. 347, $32\left(2^{\text {nd }}\right.$ Ed)

Islam, M. S.; Saito, T. and Kurasaki, M. 2015. Phytofiltration of arsenic and cadmium using Micranthemum umbrosum: Phytotoxicity, uptake kinetics and mechanism. Ecotoxicology and Environmental Safety, 112:193-200

Jlassi, A.; Zorrig, W.; Khouni, A. E.; Lakhdar, A.; Smaoui, A.; Abdelly, C. and Rabhi, M. 2013. Phytodesalination of a moderately-salt-affected soil by Sulla carnosa. International Journal of Phytoremediation, 15:398-404

Karim, M. F. and Mimura, N. 2008. Impacts ofClimate Changeand Sea-level on Cyclonic Storm Surge Floods in Bangladesh, Glob. Environ. Change, 18: 490-500.

Page, A. L.; Miller, R. H. and Keeney, D. R. 1982. Methods of Soil Analysis. 2nd Edn., Amercen Society of Agronomy, Madison, WI., USA.
Rabhi, M.; Ferchichi, S.; Jouini, J.; Hamrouni, M. H,; Koyro, H. W.; Ranieri, A.; Abdelly, C. and Smaoui, A. 2010. Phytodesalination of a saltaffected soil with the halophyte Sesuvium portulacastrum $\mathrm{L}$. to arrange in advance the requirements for the successful growth of a glycophytic crop. Bioresour Technol., 101:68226828.

Ravindran, K. C.; Venkatesan, K.; Balakrishnan, V; Chel- lappan, K. P. and Balasubramanian, T. 2007. Restoration of saline land by halophytes for Indian soils, Soil Biology and Biochemistry, 39(10): 26612664.

Skoog, D. A.; West, D. M. and Holler, F. J. 1996. Fundamentals of Analytical Chemistry, $7^{\text {th }}$ Edition, Thomson Learning, Inc, USA. 